\title{
Role of $\mathrm{CD} 8^{+} \mathrm{T}$ cells in protection against Leishmania donovani infection in healed Visceral Leishmaniasis individuals
}

\author{
Himanshu Kaushall, Rachel Bras-Gonçalves ${ }^{2}$, Narender Singh Negi ${ }^{3}$, Jean-Loup Lemesre ${ }^{2}$, Gérard Papierok ${ }^{4}$ \\ and Poonam Salotra ${ }^{1 *}$
}

\begin{abstract}
Background: Majority of individuals with history of visceral leishmaniasis (VL) exhibit strong immunity to re-infection, however, the mechanism of resistance is poorly understood. It is unclear whether $\mathrm{CD} 8^{+} \mathrm{T}$ cells contribute to protection against Leishmania donovani infection through cytotoxic activity. The present study aims to evaluate immunological mechanism associated with resistance to the disease in healed VL (HVL) individuals and further, the contribution of $\mathrm{CD}^{+} \mathrm{T}$ cells in the protective immunity.

Methods: Peripheral blood mononuclear cells (PBMCs) from VL, HVL and naive groups were exposed in vitro to total soluble Leishmania antigen (TSLA) from L. donovani. The proliferation index was determined by ELISA based lymphoproliferative assay. Cytokines and granzyme B levels were measured by CBA. Activated T-cell populations were estimated using flow cytometry.

Results: We observed significantly higher lymphoproliferation, cytokines and granzyme B levels in HVL group compared to naive or VL group. More strikingly, we found a strong association $\left(r_{s}=0.895, P<0.0001\right)$ between proliferation index (PI) and granzyme B level, with a significant proportion of activated CD8 ${ }^{+} \mathrm{T}$ cells in HVL group.

Conclusions: Leishmania immune group (HVL) exhibited durable and strong cellular immune response to TSLA in terms of lymphoproliferation as well as production of Th1 cytokines and granzyme B. Additionally, the elevated level of activated $C D 8^{+} T$ cells and stimulation of cytotoxic activity through granzyme B production, indicated a possible role of $\mathrm{CD}^{+} \mathrm{T}$ cells in resistance to $L$. donovani infection in the HVL group.
\end{abstract}

Keywords: $\mathrm{CD}^{+}$T cells, Granzyme B, Visceral leishmaniasis, Total soluble Leishmania antigens, Vaccine

\section{Background}

Leishmaniasis is a neglected tropical disease which poses risk to over 350 million people worldwide, in 98 countries or territories [1]. Depending on the species, the disease manifests into different clinical forms, ranging from self-healing cutaneous leishmaniasis (CL) to disfiguring mucosal lesions to the visceral form, visceral leishmaniasis (VL). Of these, VL is the most severe form which proves fatal if diagnosed late or left untreated. Currently, more than $90 \%$ of annual incidence of VL occurs in countries like India, Sudan, Bangladesh, Brazil, Ethiopia

\footnotetext{
* Correspondence: salotrap@icmr.org.in

${ }^{1}$ National Institute of Pathology (ICMR), Safdarjung Hospital Campus, New Delhi 110029 , India

Full list of author information is available at the end of the article
}

and the Nepal $[2,3]$. In India, about $5-10 \%$ of apparently healed VL patients develop an unusual dermal form of the disease termed Post-kala azar dermal leishmaniasis (PKDL) which constitutes an important reservoir for the parasites [4].

Previous studies have shown that majority of individuals who had VL or asymptomatic infection acquired strong immunity against re-infection with the same subspecies $[5,6]$. This observation strongly advocates the development of an anti-leishmanial vaccine which could induce a long lasting immunity similar to that acquired naturally in healed visceral leishmaniasis (HVL) individuals. However, understanding the immunological mechanism associated with resistance and susceptibility to disease 
is of utmost importance for the design and evaluation of a vaccine. This aspect is understudied in human VL although several reports are available in murine models for both CL and VL.

Immunopathology of human VL presents a mixed Thelper 1 (Th1)/T-helper 2 (Th2) cytokine response, and is characterized by the presence of a dominant Th2 response over Th1 response. However, this response gets reversed in HVL individuals with up regulation of Th1 response $[7,8]$. The T lymphocyte profile of peripheral blood mononuclear cells (PBMCs) of active VL patients have higher proportion of $\mathrm{CD}^{+} \mathrm{T}$ cells compared to $\mathrm{CD}^{+} \mathrm{T}$ cells which approach normal levels post-treatment $[9,10]$. Furthermore, it was recently revealed that there is complete anergic/exhaustion in $\mathrm{CD}^{+} \mathrm{T}$ cells in chronic VL patients, with limited ability to contribute IFN- $\gamma[11]$.

In experimental models, the role of $\mathrm{CD}^{+} \mathrm{T}$ cells in the control of murine CL and determination of resistance to re-infection remains contradictory. However, $\mathrm{CD}^{+} \mathrm{T}$ cells have been thought to play a major role in murine VL. $\mathrm{CD}^{+} \mathrm{T}$ cells participate not only in primary but also in subsequent infection with Leishmania donovani [12]. One study revealed that purified $\mathrm{CD}^{+} \mathrm{T}$ cells from the mice infected with $L$. infantum expressed Th1 cytokines (IFN- $\gamma$ and TNF- $\alpha$ ), and showed considerable cytotoxic activity [13]. Another study in murine model suggested that $L$. donovani escapes cellular responses by inducing exhaustion in $\mathrm{CD}^{+} \mathrm{T}$ cells [14], however, in canine VL, both $\mathrm{CD}^{+}$and $\mathrm{CD}^{+} \mathrm{T}$ cells show Programmed Death1 mediated exhaustion, which impairs their phagocyte function [15].

In human leishmaniasis, the role of $\mathrm{CD}^{+} \mathrm{T}$ cells is not clear and depends largely on the species and the corresponding disease. Limited studies have been carried out with VL patients and ascribe a protective role for $\mathrm{CD}^{+} \mathrm{T}$ cells, which is similar as in mice models. One earlier study showed involvement of not only IFN- $\gamma$ producing $\mathrm{CD}^{+} \mathrm{T}$ cells, but also $\mathrm{CD}^{+} \mathrm{T}$ cells in the control of L. infantum infection [16]. In human CL, the exact role of $\mathrm{CD}^{+} \mathrm{T}$ cells is unclear. In a recent study, a major correlation was observed between protection and the $\mathrm{CD}^{+} \mathrm{T}$ cells producing IFN- $\gamma$ after re-stimulation [17]. In humans, several studies suggest that $\mathrm{CD}^{+} \mathrm{T}$ cells mediate protection through cytotoxicity against intracellular pathogens, such as Trypanosoma cruzi and Mycobacterium tuberculosis [18-20]. However, it is unclear whether $\mathrm{CD}^{+} \mathrm{T}$ cells contribute protection against $L$. donovani parasites through the cytotoxic activity.

In the present study, Leishmania-specific cellular immune responses upon in vitro stimulation of PBMCs with total soluble Leishmania antigen (TSLA) were evaluated in VL, HVL and naive groups by measuring lymphoproliferation, cytokines, granzyme B and the proportion of activated $\mathrm{T}$ cell populations. The data suggested the possible role of effector $\mathrm{CD}^{+} \mathrm{T}$ cells in resistance to $L$. donovani infection in HVL individuals.

\section{Methods}

Study subjects

Our study included active VL $(\mathrm{n}=11)$, HVL $(\mathrm{n}=16)$ and naive $(n=19)$ individuals, all seronegative for HIV and above sixteen years of age. Patients clinically diagnosed with VL (age range in years, 17-62; age mean $\pm S D$, $36.54 \pm 14.37$ ), were admitted to Department of Medicine, Safdarjung Hospital, New Delhi. Active VL was diagnosed with the clinical features such as fever, hepatosplenomegaly, anaemia, weight loss, and pancytopenia and positive rK39 strip test. VL was confirmed by presence of Leishman-Donovan (LD) bodies and/or by PCR in bone marrow aspirates. Individuals included in HVL group (age range in years, 19-48; age mean \pm SD 31.4 \pm 9.19 ) were healthy individuals that had completed VL treatment at least one year back. The range of post-treatment duration for the HVL group was 1 to $20 \mathrm{yrs}$, with mean \pm SD $11 \pm 5.76$ in yrs. They were all positive for rK39 strip test and majority $(15 / 16)$ were PCR negative. Blood samples of 19 naive individuals (age range, 18-35; age mean \pm SD $26.89 \pm 4.56)$ were included in this study. All naive individuals were negative for rK39 strip test and for lymphoproliferative assay.

\section{Ethics statement}

The study was approved by and carried out under the guidelines of the ethical committee of the Safdarjung Hospital, India. All individuals under study provided written informed consent for the collection of samples and subsequent analysis.

\section{Preparation of Total Soluble Leishmania antigen (TSLA)}

Promastigotes of L. donovani (MHOM/IN/80/Ldd8Cl2) were harvested in stationary phase, washed and the pellet resuspended in the lysing solution (50 mM Tris/5 mM EDTA/HCl, pH7). After three cycles of freezing/thawing, the samples were subjected to three pulses of 20 seconds at $40 \mathrm{~W}$ with sonicator, at one minute interval. The sample was centrifuged at $5000 \times \mathrm{g}$ for $20 \mathrm{~min}$ at $4^{\circ} \mathrm{C}$, and supernatant was collected. Protein content was estimated using Bradford method. TSLA was aliquoted and stored at $-80^{\circ} \mathrm{C}$ until further use.

\section{Lymphoproliferative assay}

PBMCs were isolated from the heparinised blood samples by density sedimentation (Ficoll-PaqueTM PLUS; GE Healthcare), washed, resuspended in RPMI 1640 supplemented with $10 \% \mathrm{FCS}$, penicillin $(100 \mathrm{U} / \mathrm{ml})$, and streptomycin $(100 \mu \mathrm{g} / \mathrm{ml})$. PBMCs at concentration of $1 \times 10^{6}$ cells $/ \mathrm{ml}$ were cultured in triplicate in 96-well flatbottom tissue culture plates (Axygen, Union city, CA, 
USA) and stimulated with TSLA $(10 \mu \mathrm{g} / \mathrm{ml})$ or PHA-M $(10 \mu \mathrm{g} / \mathrm{ml})$ for $120 \mathrm{hrs}$ in humidified $37^{\circ} \mathrm{C} / 5 \% \mathrm{CO}_{2}$ incubator. At 104-106 hrs incubation, $20 \mu \mathrm{L}$ BrdU labelling solution was added and samples reincubated in humidified $37^{\circ} \mathrm{C} / 5 \% \mathrm{CO}_{2}$ incubator for another $16-$ 18 hrs. Lymphoproliferation was evaluated by commercially available kit (BiotrakTM cell proliferation ELISA system, version 2, GE Healthcare) using ELISA method. The proliferation index (PI) was calculated as the ratio of optical density (OD) of stimulated cultures and unstimulated cultures for each sample. Cell proliferation was considered significant when PI was above cut-off (mean $+3 \mathrm{SD})$.

\section{Estimation of cytokines and granzyme B in culture supernatant}

PBMCs of active VL, HVL and naive individuals were incubated with TSLA for 120 hrs as described above. The tissue culture plates were centrifuged and supernatants were collected and stored at $-80^{\circ} \mathrm{C}$ until use. Cytokines (IFN- $\gamma$, TNF- $\alpha$ and IL-10) and granzyme B levels were analysed by utilising cytometric bead array (CBA) flex sets (BD Biosciences) and measuring fluorescence by flow cytometry according to manufacturer's recommendations. Samples were acquired on flow cytometer, BD FACSCalibur using BD CellQuest Pro software and the data were analysed using FCAP array software (BD Biosciences). The assay sensitivity for IFN- $\gamma$, TNF- $\alpha$, IL-10 and granzyme $\mathrm{B}$ were $1.8,1.2,0.13$ and $4 \mathrm{pg} / \mathrm{ml}$ respectively.

\section{Flow cytometer analysis for cell surface phenotype of activated $\mathrm{T}$ cell populations}

Detection of activation in $\mathrm{CD}^{+}$or $\mathrm{CD}^{+} \mathrm{T}$ cells were done by freshly isolated PBMCs $\left(10^{6} / \mathrm{ml}\right)$ from eight HVL and eight naive individuals within recruited individuals for this study, and incubated with TSLA $(10 \mu \mathrm{g} / \mathrm{ml})$ in a 96well flat-bottom plate for $120 \mathrm{hrs}$ at $37^{\circ} \mathrm{C}$. After $120 \mathrm{hrs}$, the cells were harvested, washed with staining buffer (0.02 M PBS, 1\% FBS, and 0.01\% sodium azide), and surface stained with fluorochrome-conjugated antibodies to CD3-FITC, CD4-PerCP-Cy5.5, CD8-PerCP-Cy5.5 and CD69-APC, along with appropriate isotype controls (BD Biosciences) for $30 \mathrm{~min}$ at $4^{\circ} \mathrm{C}$. Cells were then washed and finally suspended in $500 \mu \mathrm{l}$ staining buffer (BD Biosciences). Samples were acquired and analyzed on flow cytometer, BD FACSCalibur using BD CellQuest Pro software on at least 10,000 events. Analysis gates were set for lymphocytes using forward and side scatter properties and the frequencies of activated $\mathrm{CD}^{+}$and $\mathrm{CD}^{+} \mathrm{T}$ cells were acquired onCD ${ }^{+} \mathrm{T}$ cells. Cell viability using 7AAD staining (BD) of a limited number of samples confirmed that the gated lymphocytes were $>99 \%$ viable for both HVL and naive groups.

\section{Statistical analysis}

Results are represented as mean \pm SE. Data were analysed using GraphPad Prism 5.0 (GraphPad Software, San Diego, CA). Statistical significance were determined by nonparametric Mann-Whitney test between two groups and by Kruskal-Wallis test followed by the post hoc Dunn multiple comparison test for more than two groups. Correlation was calculated by Spearman rank correlation test. The statistical tests were two-tailed and $p$ values $<0.05$ were considered significant.

\section{Results}

Proliferative response of peripheral lymphocytes to L. donovani TSLA

Cell-Mediated Immune (CMI) response was analyzed in terms of lymphoproliferative response in vitro to TSLA and phytohemagglutinin (PHA). PHA served as positive control and every individual of the three study group showed high stimulation (Naive PI mean \pm SE, $10.30 \pm$ 3.649; VL, $7.73 \pm 3.893$; HVL, $11.30 \pm 3.03$ ). Every individual in HVL group responded positively to TSLA and the group mean (PI mean \pm SE, $5.99 \pm 0.497$ ), was found significantly high $(p<0.001)$ compared to naive group (PI mean \pm SE, $1.19 \pm 0.064$ ) or active VL (PI mean \pm SE, $1.22 \pm 0.124$ ) (Figure 1). The response in active VL was found comparable to naive group ( $p=0.546)$.

\section{Estimation of cytokines upon TSLA stimulation}

PBMCs from active VL, HVL and naive groups were screened for cytokines profile in response to TSLA (Figure 2A-C). In HVL group, the CMI response (as judged from the secretion of Th1 cytokines, IFN- $\gamma$ and TNF- $\alpha$ ) was found significantly higher than the naive or

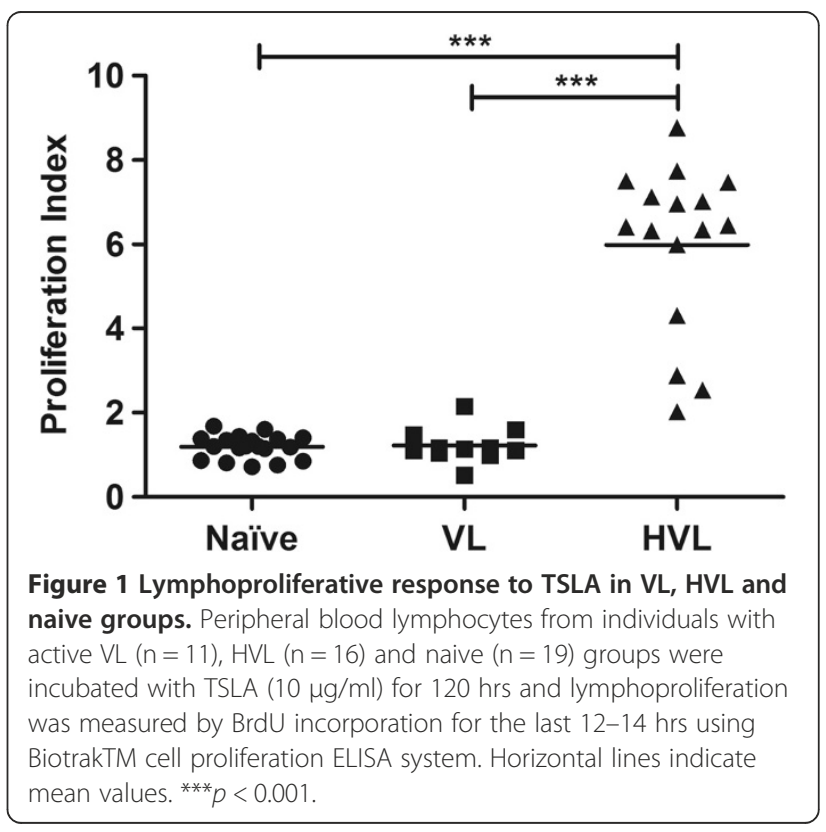



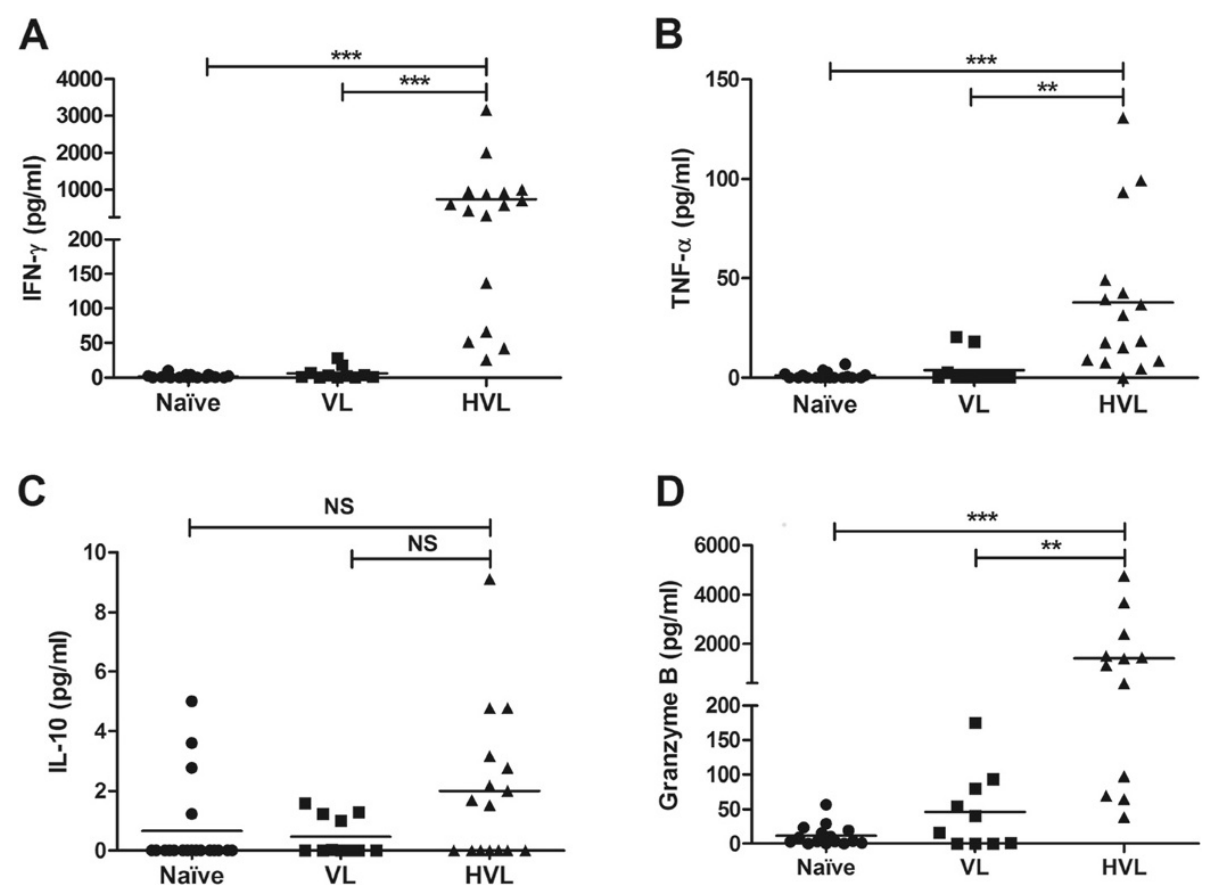

Figure 2 In vitro Leishmania-specific cellular immune response in VL, HVL and naive groups. PBMCs were isolated and incubated with TSLA $(10 \mu \mathrm{g} / \mathrm{ml})$ for 120 hrs. (A-C) Cytokines (IFN- $\gamma$, TNF-a and IL-10) were measured in the supernatant of VL $(n=11), H V L(n=16)$ and naive $(n=19)$ and (D) Granzyme B were analyzed in the supernatant of $V L(n=11), H V L(n=12)$ and naive $(n=16)$ using CBA. Horizontal lines indicate mean values. NS, Not Significant, ${ }^{* *} p<0.01,{ }^{* * *} p<0.001$.

active VL. HVL group (mean \pm SE, $738.44 \pm 206.21$ ) showed significantly high $(p<0.001)$ IFN- $\gamma$ level compared to naive (mean $\pm \mathrm{SE}, 1.80 \pm 0.57$ ) or active $\mathrm{VL}$ (mean \pm SE, $10.63 \pm 2.76)$. Cut off (Mean $+3 \mathrm{SD})$ value for IFN- $\gamma$ was determined as $9.33 \mathrm{pg} / \mathrm{ml}$ and, importantly, every HVL individual showed IFN- $\gamma$ level above cut-off value. Similarly, significantly high TNF- $\alpha$ production was observed in response to TSLA stimulation in HVL group (mean $\pm \mathrm{SE}, 37.71 \pm 9.59$ ) compared to naive (mean $\pm \mathrm{SE}$, $1.01 \pm 0.43, p<0.001)$ or active VL (mean \pm SE, $3.77 \pm$ $2.33, p<0.01)$. For IL-10 cytokine, the measured values for $\mathrm{HVL}$ (mean $\pm \mathrm{SE}, 2 \pm 0.63$ ) were low, and comparable to naive, (mean $\pm \mathrm{SE}, 0.66 \pm 0.33$ ) or active $\mathrm{VL}$ (mean $\pm \mathrm{SE}$, $0.69 \pm 0.19)$.

\section{Granzyme B analysis}

Granzyme B, a serine proteinase produced by the cytotoxic lymphocytes, notably, induces rapid cellular death of the target by apoptosis. Here, granzyme B was measured in culture supernatant upon in vitro TSLA stimulation of PBMCs. The granzyme B level of HVL group (mean \pm SE, $1411.91 \pm 441.62)$, was found significantly high compared to naive (mean $\pm \mathrm{SE}, 11.79 \pm 3.98, p<0.001$ ) or active $\mathrm{VL}$ group (mean $\pm \mathrm{SE}, 45.97 \pm 18.08, p<0.01$ ), with $11 / 12$ (92\%) HVL individuals showing values above cut off value $(58.10 \mathrm{pg} / \mathrm{ml})$ (Figure 2D). Mean of active VL group was found comparable to naive $(p=0.371)$.

\section{Correlation between granzyme B level and proliferation index}

The secretion of granzyme B upon TSLA stimulation were analysed in active VL, HVL and naive group with the respective proliferation index. In HVL group, the level of granzyme $\mathrm{B}$ was found strongly correlated with PI $\left(r_{s}=0.895, p<0.0001\right)$ (Figure 3). Besides, we observed moderately significant correlation between PI and IFN- $\gamma$ and TNF- $\alpha$ with $r_{s}=0.63(p=0.03)$ and $r_{s}=0.62$ $(p=0.03)$ respectively in HVL group. However, we did not observe any significant correlation between granzyme B and IFN- $\gamma$ level $\left(r_{\mathrm{s}}=0.434, p=0.158\right)$ in the culture supernatant.

\section{Estimation of activated T lymphocytes}

The strong association between PI and granzyme B in the HVL group, provided lead for the possible protective role of $\mathrm{CD}^{+} \mathrm{T}$ cells. Therefore, using CD69 as a marker of activation [21], we investigated the percentage of activated $\mathrm{CD}^{+}$and $\mathrm{CD}^{+} \mathrm{T}$ cell populations upon in vitro TSLA stimulation both in HVL and naive groups. $\mathrm{CD} 8^{+} \mathrm{T}$ cells showed a pronounced activation in HVL, with significantly higher percentage of $\mathrm{CD}^{+} \mathrm{CD} 69^{+} \mathrm{T}$ cell population in HVL group (mean $\pm \mathrm{SE}, 7.99 \pm 0.91, p=0.0002$ ) compared to naive group (mean $\pm \mathrm{SE}, 0.67 \pm 0.19$ ). There was also a significantly higher percentage of $\mathrm{CD} 4{ }^{+} \mathrm{CD} 69^{+} \mathrm{T}$ cell 


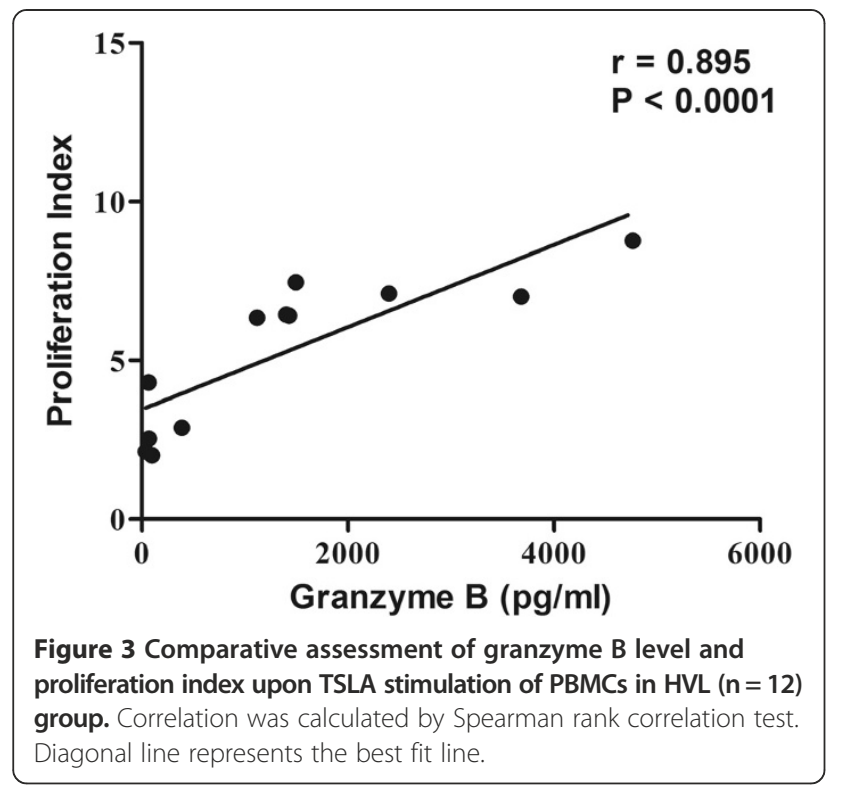

(mean $\pm \mathrm{SE}, 3.12 \pm 0.44, p=0.0047$ ) in HVL compared to naive group (mean \pm SE $0.46 \pm 0.07$ ) (Figure 4).

\section{Discussion}

In the present study, we initially evaluated CMI response in terms of lymphoproliferation upon in vitro TSLA stimulation in active VL, HVL and naive groups. We demonstrated significantly high lymphoproliferation in Leishmania immune group (HVL) implying the presence of circulating Leishmania-specific memory $\mathrm{T}$ cells which showed significantly higher lymphoproliferation compared to that in unexposed individuals (naive). On the contrary, active VL group failed to show lymphoproliferation which indicated immune dysfunction [11,22]. Besides, earlier studies investigated cellular immune responses in HVL individuals with short VL history (up to 1 year) $[11,23,24]$ whereas the present study included individuals with long history of VL ( 1 to $20 \mathrm{yrs}$, mean \pm SD, $11 \pm 5.76$ yrs) with all cases showing PI values well above cut-off, indicating

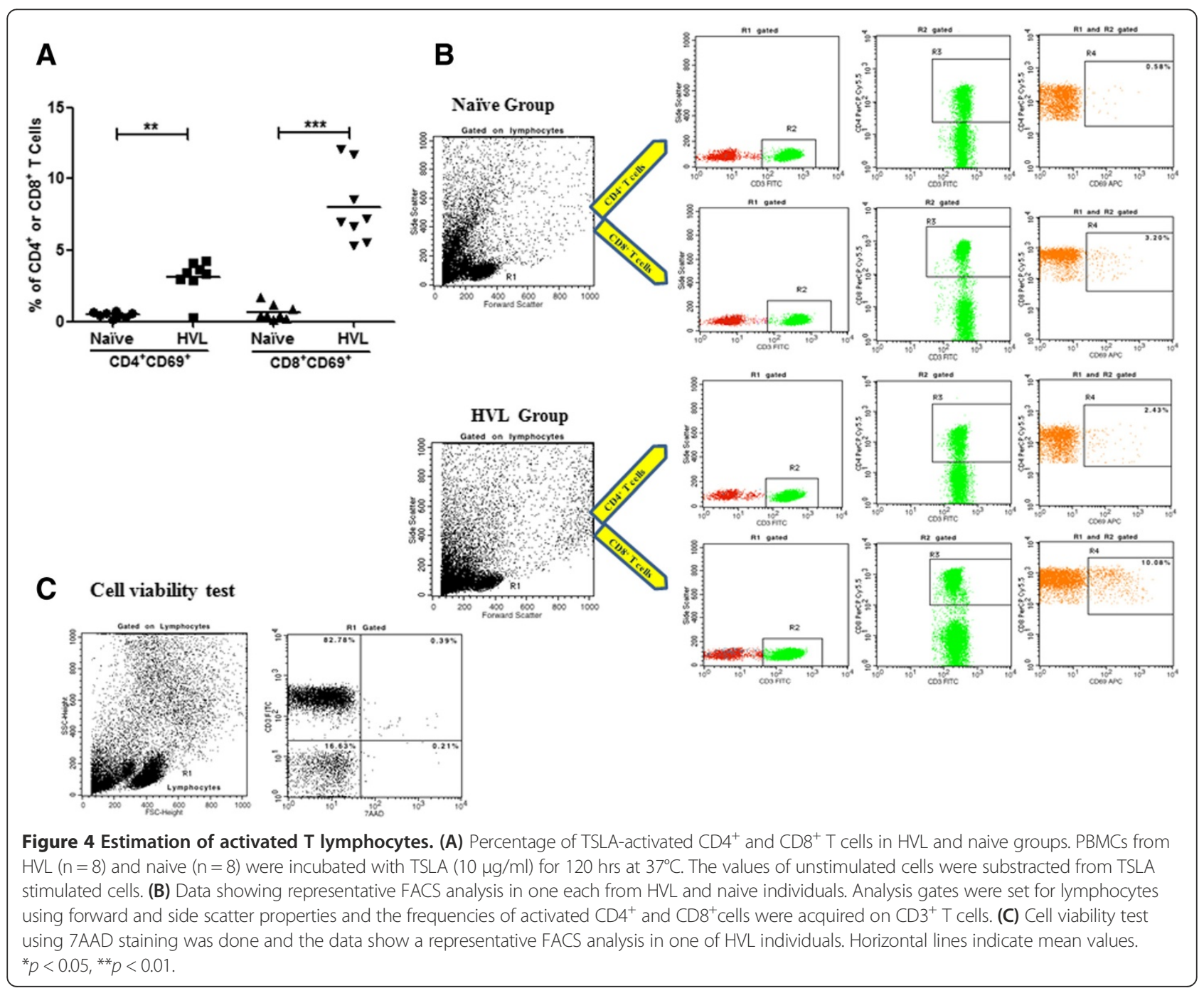


that an anti-leishmanial vaccine could provide long term protection to Leishmania infection.

The cytokine analysis constitutes an important part since they form a complex network of synergistic and antagonistic interactions which not only induce but also control immune response. IFN- $\gamma$, produced predominantly by activated CD4 Th1 and CD8 cytotoxic T lymphocyte (CTL) and NK cells in response to IL-12 signaling, is an important activator of macrophages that enhances their microbicidal activity against intracellular pathogens $[25,26]$. It promotes NO production by inducing iNOS (inducible nitric oxide synthase) expression by infected phagocytes thus facilitating elimination of parasites and resolving Leishmania infection [27]. Another Th1 cytokine, tumor necrosis factor alpha (TNF- $\alpha$ ), known to exert cytotoxic effects on pathogens, has been closely associated with VL pathogenesis, being low in active VL and getting restored after treatment [28]. The cytokine profile upon TSLA stimulation of PBMCs corroborates our lymphoproliferation data. The production of significantly higher level of Th1 cytokines (IFN- $\gamma$ and TNF- $\alpha$ ) to TSLA was observed in HVL group compared to naive or active VL group and is in accordance with earlier studies [29-31]. The significant association between PI and IFN- $\gamma$ and TNF- $\alpha$ in HVL group indicates the strong CMI in individuals with prior exposure to Leishmania antigens. As expected, no protective immune response was observed in naive individuals while the active VL group exhibited peripheral lymphocytes anergy [22]. IL-10 on the other hand has counter regulatory role against IL-12 and IFN- $\gamma$ and thus favours the survival of Leishmania parasites by inhibiting NO-mediated killing [32]. We observed no significant difference in IL-10 production between the different study groups.

There are mainly two mechanisms by which cytotoxic cells lyse their targets: the perforin-granzyme B pathway and death receptors (Fas/FasL) [33,34]. The FasLdependent pathway utilises Fas surface receptor by Fas ligand expressed on the surface of the CTL and NK Cells, which triggers Fas-mediated apoptosis in target cells. The chief mechanism used by cytotoxic cells to induce target cell death is through the granule exocytosis pathway and depends on the concerted action of effector molecules contained in the cytolytic granules. These granules contain perforin, the pore-forming molecule, together with granule-associated enzymes. Among them, granzyme B is the most important effector molecule for target-cell apoptosis [35]. It is unclear whether $\mathrm{CD} 8^{+}$ $T$ cells contribute protection against $L$. donovani parasites through their cytotoxic activity. Limited studies have been conducted dealing with parasite-specific cell-mediated cytotoxicity in VL, CL or mucocutaneous leishmaniasis [31,36-38]. Here, we evaluated granzyme B level to investigate whether individuals healed after $L$. donovani infection develops a cytotoxic immune response upon reexposure. We demonstrated significantly higher granzyme B level upon TSLA stimulation in Leishmania immune (HVL) group compared to naive or VL group, with a strong association between PI and granzyme B level. Previous studies with viral infections have shown that granzyme $\mathrm{B}$ is predominantly secreted by $\mathrm{CD}^{+} \mathrm{T}$ cells [39], although, the contributions of NK cells and CD4 $4^{+}$ cytotoxic cells have also been suggested $[40,41]$. Furthermore, we observed a significantly high percentage of $\mathrm{CD}^{+} \mathrm{CD} 9^{+}$and $\mathrm{CD} 4^{+} \mathrm{CD} 69^{+} \mathrm{T}$ cells in the healed $\mathrm{VL}$ individuals. This is distinct from the report in cured $\mathrm{CL}$ individuals where a high $\mathrm{CD} 4^{+} \mathrm{CD} 69^{+} \mathrm{T}$ cells was demonstrated to be responsible for the immunity to L. major infection [31].

\section{Conclusion}

The study brings forth some essential points regarding the immunological mechanism associated with resistance to VL in healed VL individuals with long history of $\mathrm{VL}$. The preponderance of $\mathrm{CD} 8^{+} \mathrm{T}$ cells was suggested in resistance to $L$. donovani infection possibly via the perforin-granzyme B pathway and by the activation of significant proportion of $\mathrm{CD}^{+}{ }^{+} \mathrm{T}$ cell populations. The findings support the role of $\mathrm{CD}^{+} \mathrm{T}$ cells in resistance to Leishmania infection, which could be exploited for the design and evaluation of a vaccine.

\section{Abbreviations \\ VL: Visceral leishmaniasis; PKDL: Post kala-azar dermal Leishmaniasis; \\ CL: Cutaneous leishmaniasis; IL: Interleukin; IFN: Interferon; Th: T Helper cell; \\ TNF: Tumour necrosis factor; TSLA: Total soluble Leishmania antigen; \\ PBMCs: Peripheral blood mononuclear cells.}

\section{Competing interests}

The authors declare that they have no competing interests.

\section{Authors' contributions}

Conceived and designed the experiments: RB-G, PS, J-LL, HK and RAPSODI Consortium. Performed the experiments: HK. Analyzed the data: HK and PS. Contributed reagents/materials/analysis tools: PS, NSN, RB-G., J-LL, and GP. Wrote the paper: HK and PS. All authors read and approved the final manuscript.

\section{Acknowledgements}

Mr. Himanshu Kaushal is receipt of a Senior Research Fellowship from the Indian Council of Medical Research (ICMR), Government of India. This work received financial assistance from the European Commission project, RAPSODI.

\section{Author details}

${ }^{1}$ National Institute of Pathology (ICMR), Safdarjung Hospital Campus, New Delhi 110029, India. ${ }^{2}$ Institut de Recherche pour le Développement, UMR177 IRD/CIRAD "INTERTRYP", Montpellier, France. ${ }^{3}$ Department of Medicine, VMMC \& Safdarjung Hospital, New Delhi, India. ${ }^{4}$ Virbac, Carros, France.

Received: 15 May 2014 Accepted: 29 October 2014

Published online: 03 December 2014

\section{References}

1. World Health Organization: Control of the Leishmaniases. World Health Organ Tech Rep Ser 2010, 949:91-106. 
2. Alvar J, Yactayo S, Bern C: Leishmaniasis and poverty. Trends Parasitol 2006, 22:52-57.

3. Alvar J, Vélez ID, Bern C, Herrero M, Desjeux P, Cano J, Jannin J, den Boer M, WHO Leishmaniasis Control Team: Leishmaniasis worldwide and global estimates of its incidence. PLOS One 2012, 7:e35671.

4. Ramesh V, Singh R, Salotra P: Post-kala-azar dermal leishmaniasis - an appraisal. Trop Med Int Health 2007, 12:848-851.

5. Manson-Bahr PE: Immunity in kala-azar. Trans R Soc Trop Med Hyg 1961, 55:550-555.

6. Haldar JP, Ghose S, Saha KC, Ghose AC: Cell-mediated immune response in Indian kala-azar and post-kala-azar dermal leishmaniasis. Infect Immun 1983, 42:702-707.

7. Hailu A, Menon JN, Berhe N, Gedamu L, Hassard TH, Kager PA, Olobo J, Bretscher PA: Distinct immunity in patients with visceral leishmaniasis from that in subclinically infected and drug-cured people: implications for the mechanism underlying drug cure. J Infect Dis 2001, 184:112-115.

8. Kubar J, Fragaki K: Recombinant DNA-derived Leishmania proteins: from the laboratory to the field. Lancet Infect Dis 2005, 5:107-114

9. Saha S, Mondal S, Banerjee A, Ghose J, Bhowmick S, Ali N: Immune responses in kala-azar. Indian J Med Res 2006, 123:245-266.

10. Clarêncio J, de Oliveira Cl, Favali C, Medina O, Caldas A, Costa CH, Costa DL, Brodskyn C, Barral A, Barral-Netto M: Could the lower frequency of $\mathrm{CD} 8^{+} \mathrm{CD} 18^{+}$ $\mathrm{CD} 5 \mathrm{RO}^{+}$lymphocytes be biomarkers of human VL? Int Immunol 2009, 21:137-144.

11. Gautam S, Kumar R, Singh N, Singh AK, Rai M, Sacks D, Sundar S, Nylén S: CD8 T cell exhaustion in human visceral leishmaniasis. J Infect Dis 2014, 209:290-299.

12. Stern JJ, Oca MJ, Rubin BY, Anderson SL, Murray HW: Role of L3T4+ and LyT-2+ cells in experimental visceral leishmaniasis. J Immunol 1988, 140:3971-3977.

13. Tsagozis P, Karagouni E, Dotsika E: CD8 (+) T cells with parasite-specific cytotoxic activity and a Tc1 profile of cytokine and chemokine secretion develop in experimental visceral leishmaniasis. Parasite Immunol 2003, 25:569-579.

14. Joshi T, Rodriguez S, Perovic V, Cockburn IA, Stäger S: B7-H1 Blockade Increases Survival of Dysfunctional CD8+ T Cells and Confers Protection against Leishmania donovani Infections. PLOS Pathog 2009, 5:e1000431.

15. Esch KJ, Juelsgaard R, Martinez PA, Jones DE, Petersen CA: Programmed death 1-mediated T cell exhaustion during visceral leishmaniasis impairs phagocyte function. J Immunol 2013, 191:5542-5550.

16. Mary C, Auriault V, Faugere B, Dessein AJ: Control of Leishmania infantum infection is associated with CD8 (+) and gamma interferon and interleukin-5-producing CD4 (+) antigen-specific T cells. Infect Immun 1999, 67:5559-5566

17. Nateghi Rostami M, Keshavarz H, Edalat R, Sarrafnejad A, Shahrestani T, Mahboudi F, Khamesipour A: CD8+ T cells as a source of IFN-gamma production in human cutaneous leishmaniasis. PLoS Negl Trop Dis 2010, 4:e845.

18. Wizel B, Palmieri M, Mendoza C, Arana B, Sidney J, Sette A, Tarleton R: Human infection with Trypanosoma cruzi induces parasite antigen-specific cytotoxic T lymphocyte responses. J Clin Invest 1998, 102:1062-1071.

19. Smith SM, Malin AS, Pauline T, Lukey, Atkinson SE, Content J, Huygen K, Dockrell HM: Characterization of human Mycobacterium bovis bacille Calmette-Gue'rin-reactive CD8+ T cells. Infect Immun 1999, 67:5223-5230.

20. Cho S, Mehra V, Thoma-Uszynski S, Stenger S, Serbina N, Mazzaccaro RJ, Flynn JL, Barnes PF, Southwood S, Celis E, Bloom BR, Modlin RL, Sette A: Antimicrobial activity of MHC class I-restricted CD8+ T cells in human tuberculosis. Proc Natl Acad Sci U S A 2000, 97:12210-12215.

21. Arvå $E$, Andersson $B$ : Kinetics of cytokine release and expression of lymphocyte cell-surface activation markers after in vitro stimulation of human peripheral blood mononuclear cells with Streptococcus pneumoniae. Scand J Immunol 1999, 49:237-243.

22. Goto H, Prianti MD: Immunoactivation and immunopathogeny during active visceral leishmaniasis. Rev Inst Med Trop Sao Paulo 2009, 51:241-246.

23. Kushawaha PK, Gupta R, Tripathi CD, Sundar S, Dube A: Evaluation of Leishmania donovani protein disulfide isomerase as a potential immunogenic protein/vaccine candidate against visceral Leishmaniasis. PLoS One 2012, 7:e35670.

24. Saha S, Mondal S, Ravindran R, Bhowmick S, Modak D, Mallick S, Rahman M, Kar S, Goswami R, Guha SK, Pramanik N, Saha B, Ali N: IL-10- and TGFbeta-mediated susceptibility in kala-azar and post-kala-azar dermal leishmaniasis: the significance of amphotericin B in the control of Leishmania donovani infection in India. J Immunol 2007, 179:5592-5603.

25. Ghosh DJ, Levy DE, Johnstone RW, Clarke CJ: IFNy signaling- does it mean JAK-STAT? Cytokine Growth Factor Rev 2008, 19:282-394.

26. Mosser DM, Edwards JP: Exploring the full spectrum of macrophage activation. Nat Rev Immunol 2008, 8:958-969.

27. Sacks D, Noben-Trauth N: The immunology of susceptibility and resistance to Leishmania major in mice. Nat Rev Immunol 2002, 2:845-858.

28. Peruhype-Magalhães $V$, Martins-Filho $O A$, Prata A, de Silva L, Rabello A, Teixeira-Carvalho A, Figueiredo RM, Guimarães-Carvalho SF, Ferrari TC, Van Weyenbergh J, Correa-Oliveira R: Mixed inflammatory/regulatory cytokine profile marked by simultaneous raise of interferon-gamma and interleukin-10 and low frequency of tumour necrosis factor-alpha $(+)$ monocytes are hallmarks of active human visceral Leishmaniasis due to Leishmania chagasi infection. Clin Exp Immunol 2006, 46:124-132.

29. Ghalib HW, Whittle JA, Kubin M, Hashim FA, el-Hassan AM, Grabstein KH, Trinchieri G, Reed SG: IL-12 enhances Th1-type responses in human Leishmania donovani infections. J Immunol 1995, 154:4623-4629.

30. Carvalho EM, Badaró R, Reed SG, Jones TC, Johnson WD Jr: Absence of gamma interferon and interleukin 2 production during active visceral leishmaniasis. J Clin Inves 1985, 76:2066-2069.

31. Chamakh-Ayari R, Bras-Gonçalves R, Bahi-Jaber N, Petitdidier E, MarkikouOuni W, Aoun K, Moreno J, Carrillo E, Salotra P, Kaushal H, Negi NS, Arevalo J, Falconi-Agapito F, Privat A, Cruz M, Pagniez J, Papierok GM, Rhouma FB, Torres $P$, Lemesre JL, Chenik M, Meddeb-Garnaoui A: In vitro evaluation of a soluble Leishmania promastigote surface antigen as a potential vaccine candidate against human leishmaniasis. PLoS One 2014, 9:e92708.

32. Vouldoukis I, Bécherel PA, Riveros-Moreno V, Arock M, da Silva O, Debré P, Mazier D, Mossalayi MD: Interleukin-10 and interleukin-4 inhibit intracellular killing of Leishmania infantum and Leishmania major by human macrophages by decreasing nitric oxide generation. Eur J Immun 1997 27:860-865.

33. Bousoffara T, Louzir H, Ben Salah A, Dellagi K: Analysis of granzyme B activity as a surrogate marker of Leishmania-specific cell-mediated cytotoxicity in zoonotic cutaneous leishmaniasis. J Infect Dis 2004, 189:1265-1273.

34. Kägi D, Vignaux F, Ledermann B, Bürki K, Depraetere V, Nagata S, Hengartner H, Golstein P: Fas and perforin pathways as major mechanisms of T-cellmediated cytotoxicity. Science 1994, 265:528-530.

35. Lowin B, Hahne M, Mattmann C, Tschopp J: Cytotoxic T-cell cytotoxicity is mediated through perforin and Fas lytic pathways. Nature 1994, 370:650-652.

36. Barral-Netto M, Barral A, Brodskyn C, Carvalho EM, Reed SG: Cytotoxicity in human mucosal and cutaneous leishmaniasis. Parasite Immunol 1995, 17:21-28.

37. Brodskyn Cl, Barral A, Boaventura V, Carvalho E, Barrel-Netto M: Parasitedriven in vitro human lymphocyte cytotoxicity against autologous infected macrophages from mucosal leishmaniasis. J Immunol 1997 159:4467-4473.

38. Heusel JW, Wesselschmidt RL, Shresta S, Russell JH, Ley TJ: Cytotoxic lymphocytes require granzyme $B$ for the rapid induction of DNA fragmentation and apoptosis in allogeneic target cells. Cell 1994, 76:977-987

39. McElhaney JE, Pinkoski MJ, Upshaw CM, Bleackley RC: The cell mediated cytotoxic response to influenza vaccination using an assay for granzyme B activity. J Immunol Methods 1996, 190:11-20.

40. Griffiths GM, Muller C: Expression of perforin and granzymes in vivo: potential diagnostic markers for activated cytotoxic cells. Immunol Today 1991, 12:415-419.

41. Sharp M, Terada K, Wilson A, Nader S, Kinchington PE, Ruyechan WT, Hay J, Arvin AM: Kinetics and viral protein specificity of cytotoxic T lymphocyte response in healthy adults immunized with live attenuated varicella vaccine. J Infect Dis 1992, 165:852-858.

doi:10.1186/s12879-014-0653-6

Cite this article as: Kaushal et al.: Role of $\mathrm{CD}^{+} \mathrm{T}$ cells in protection against Leishmania donovani infection in healed Visceral Leishmaniasis individuals. BMC Infectious Diseases 2014 14:653. 